\title{
Measuring the biosphere-atmosphere exchange of total reactive nitrogen by eddy covariance
}

\author{
C. Ammann ${ }^{1}$, V. Wolff ${ }^{1}$, O. Marx ${ }^{2}$, C. Brümmer ${ }^{3}$, and A. Neftel ${ }^{1}$ \\ ${ }^{1}$ Federal Research Station Agroscope ART, Zürich, Switzerland \\ ${ }^{2}$ LI-COR Biosciences GmbH, Bad Homburg vor der Höhe, Germany \\ ${ }^{3}$ Johann Heinrich von Thünen-Institute vTI, Braunschweig, Germany \\ Correspondence to: C. Ammann (christof.ammann@art.admin.ch)
}

Received: 16 April 2012 - Published in Biogeosciences Discuss.: 13 June 2012

Revised: 28 August 2012 - Accepted: 1 October 2012 - Published: 2 November 2012

\begin{abstract}
The (net) exchange of reactive nitrogen $\left(\mathrm{N}_{\mathrm{r}}\right)$ with the atmosphere is an important driver for ecosystem productivity and greenhouse gas exchange. The exchange of airborne $\mathrm{N}_{\mathrm{r}}$ includes various trace compounds that usually require different specific measurement techniques, and up to now fast response instruments suitable for eddy covariance measurements are only available for few of these compounds.

Here we present eddy covariance flux measurements with a recently introduced converter (TRANC) for the sum of all $\mathrm{N}_{\mathrm{r}}$ compounds $\left(\sum \mathrm{N}_{\mathrm{r}}\right)$. Measurements were performed over a managed grassland field with phases of net emission and net deposition of $\sum \mathrm{N}_{\mathrm{r}}$ and alternating dominance of oxidized $\left(\mathrm{NO}_{\mathrm{X}}\right)$ and reduced species $\left(\mathrm{NH}_{3}\right)$. Spectral analysis of the eddy covariance data exhibited the existence of covariance function peaks at a reasonable time lag related to the sampling tube residence time under stationary conditions. Using ogive analysis, the high-frequency damping was quantified to $19 \%-26 \%$ for a low measurement height of $1.2 \mathrm{~m}$ and to about $10 \%$ for $4.8 \mathrm{~m}$ measurement height.

$\sum \mathrm{N}_{\mathrm{r}}$ concentrations and fluxes were compared to parallel $\mathrm{NO}$ and $\mathrm{NO}_{2}$ measurements by dynamic chambers and $\mathrm{NH}_{3}$ measurements by the aerodynamic gradient technique. The average concentration results indicate that the main compounds $\mathrm{NO}_{2}$ and $\mathrm{NH}_{3}$ were converted by the TRANC system with an efficiency of near $100 \%$. With an optimised sample inlet also the fluxes of these compounds were recovered reasonably well including net deposition and net emission phases. The study shows that the TRANC system is suitable for fast response measurements of oxidized and reduced nitrogen compounds and can be used for continuous eddy covariance flux measurements of total reactive nitrogen.
\end{abstract}

\section{Introduction}

The import and loss of reactive nitrogen $\left(\mathrm{N}_{\mathrm{r}}\right)$ that can become plant available and serve as nutrient is an important driver for the species composition and growth of terrestrial ecosystems. With increasing $\mathrm{N}_{\mathrm{r}}$ deposition from the atmosphere, natural ecosystems may be disturbed severely e.g., by plant composition change, loss of biodiversity and soil acidification (Erisman et al., 2007). Therefore, international regulations have been established (UNECE, 1999) concerning critical loads (i.e., maximum tolerable annual atmospheric input) of total $\mathrm{N}_{\mathrm{r}}$ into sensitive (semi-) natural ecosystems. The recent scientific debate about the influence of nitrogen deposition on forest carbon sequestration (Magnani et al., 2007; Hogberg, 2007; Sutton et al., 2008) illustrates that the biosphere-atmosphere exchange of $\mathrm{N}_{\mathrm{r}}$ also has potentially large impacts on ecosystem productivity and, thus, on the source and sink processes of greenhouse gases (GHG). Furthermore, agricultural land is supposed to act as both sink and source for $\mathrm{N}_{\mathrm{r}}$ (e.g., Sutton et al., 2000; Flechard et al., 2010) and, therefore, plays a key role for the spatial abundance of $\mathrm{N}_{\mathrm{r}}$ in the atmospheric boundary layer. The high importance of the terrestrial biosphere as source and sink of GHG is nowadays widely recognised and corresponding research programs (e.g., GreenGrass, CarboEurope-IP, NitroEuropeIP) and flux monitoring networks (FLUXNET, ICOS) have been initiated (Baldocchi et al., 2001; Soussana et al., 2007; Skiba et al., 2009; Schulze et al., 2010). In order to understand and being able to model the GHG exchange of an investigated ecosystem, also adequate information on the nitrogen exchange is needed (e.g., Lamarque et al., 2005; Sutton et al., 2008). However, as pointed out by Flechard et al. (2011)

Published by Copernicus Publications on behalf of the European Geosciences Union. 
there is presently a serious lack of long-term $\mathrm{N}_{\mathrm{r}}$ flux measurements for European ecosystems, which hampers the validation of differing results from dry deposition models.

The exchange of $\mathrm{N}_{\mathrm{r}}$ with the atmosphere includes various oxidized and reduced trace compounds: gaseous $\mathrm{NO}, \mathrm{NO}_{2}$, $\mathrm{HONO}, \mathrm{HNO}_{3}, \mathrm{NH}_{3}$, and particulate $\mathrm{NO}_{3}^{-}, \mathrm{NH}_{4}^{+}$, beside organic nitrogenous compounds (see e.g., Farmer et al., 2006) and other minor compounds. Due to their reactivity (and water solubility) an accurate detection is generally difficult and flux measurements are further complicated by transformations on a time scale comparable to that of turbulent transport (Meixner, 1994; Nemitz et al., 2004). In the last few years, the NitroEurope project sought to monitor the complete nitrogen budget at selected European sites (Skiba et al., 2009). Various analytical techniques and different flux measurement methods have been applied simultaneously often requiring expensive and maintenance-intensive systems. For some reactive species, simpler integral monitoring systems are also used (Famulari et al., 2009; Flechard et al., 2011), but they yield only a low time resolution of one month.

For the measurement of trace gas fluxes on the ecosystem/field scale, the eddy covariance (EC) approach is considered the most direct and trustworthy experimental technique (Dabberdt et al., 1993). It is the standard method for GHG flux monitoring (Aubinet et al., 2000; Baldocchi, 2003) and is also preferable for measurements of the reactive nitrogen exchange. However, the EC method necessitates sensitive and fast response trace gas analysers (response time of $1 \mathrm{~s}$ or faster), a requirement that is difficult to fulfil for the mentioned $\mathrm{N}_{\mathrm{r}}$ compounds. While the EC technique has already been applied in a number of studies for $\mathrm{NO}$ and/or $\mathrm{NO}_{2}$ (Delany et al., 1986; Eugster et al., 1996; Civerolo and Dickerson, 1998; Li et al., 1999; Rummel et al., 2002; Horii et al., 2004), only recent exploratory studies for other $\mathrm{N}_{\mathrm{r}}$ compounds like $\mathrm{NH}_{3}$ (Whitehead et al., 2008; Sintermann et al., 2011), $\mathrm{HNO}_{3}$ and some organic nitrogen compounds (Farmer et al., 2006), or aerosol $\mathrm{NO}_{3}^{-}$and $\mathrm{NH}_{4}^{+}$(Nemitz et al., 2008; Farmer et al., 2011) have been performed. The fast and accurate detection of species like $\mathrm{NH}_{3}$ and $\mathrm{HNO}_{3}$ is often further complicated by inevitable air sampling through a (long) inlet tube where such reactive and water soluble compounds easily interact with the inner tube walls and fast variations of gas concentrations are smeared out. Integral EC fluxes of total oxidized $\mathrm{N}_{\mathrm{r}}$ compounds $\left(\mathrm{NO}_{\mathrm{y}}\right)$ have been achieved by means of a gold catalytic converter by Munger et al. (1996) and Horii et al. (2006).

Within the NitroEurope project activities Marx et al. $(2006,2012)$ proposed a thermal converter (TRANC) for the sum of all $\mathrm{N}_{\mathrm{r}}$ compounds $\left(\sum \mathrm{N}_{\mathrm{r}}\right)$. With this converter, all oxidized and reduced $\mathrm{N}_{\mathrm{r}}$ compounds are converted to $\mathrm{NO}$ directly after the sample air enters the inlet without losing the fast response information and the concentration signal is then detected by a single fast response NO analyser. The converter had been tested for efficient conversion of the main relevant $\mathrm{N}_{\mathrm{r}}$ compounds and for fast time response to NO and $\mathrm{NO}_{2}$ as presented in the companion paper by Marx et al. (2012). In the present study, we assess the applicability for EC flux measurements of varying $\mathrm{N}_{\mathrm{r}}$ compositions in the field by spectral analysis of the EC data and by validation against independent flux methods for individual $\mathrm{N}_{\mathrm{r}}$ compounds. Measurements were performed over a managed grassland field with phases of net emission and net deposition of $\sum \mathrm{N}_{\mathrm{r}}$ and alternating dominance of oxidized $\left(\mathrm{NO}_{\mathrm{X}}\right)$ and reduced species $\left(\mathrm{NH}_{3}\right)$. $\sum \mathrm{N}_{\mathrm{r}}$ fluxes were compared to parallel measurements of $\mathrm{NO}$ and $\mathrm{NO}_{2}$ fluxes by dynamic chambers and of $\mathrm{NH}_{3}$ measurements by the aerodynamic gradient technique.

\section{Methods}

\subsection{Field site}

Field measurements were performed at the Swiss FLUXNET site Oensingen $\mathrm{CH}-\mathrm{Oe} 1\left(7^{\circ} 44^{\prime} \mathrm{E}, 47^{\circ} 17^{\prime} \mathrm{N}, 450 \mathrm{~m}\right.$ a.s.1.). The investigated grassland field has been established in 2001 and is intensively managed (clover-grass mixture, 4-5 cuts per year, total fertilizer input: c. $230 \mathrm{~kg}^{-N} \mathrm{ha}^{-1} \mathrm{yr}^{-1}$ ). The site is situated on the Central Swiss Plateau in a region with intensive agriculture and other local anthropogenic influences (highway, roads, villages) that represent strong regional sources of $\mathrm{N}_{\mathrm{r}}$ compounds like $\mathrm{NH}_{3}$ and $\mathrm{NO}_{X}$. Oensingen has been a main experimental site of the European GreenGrass, CarboEurope and NitroEurope flux networks (Ammann et al., 2007, 2009). Carbon and energy flux measurements and a large number of basic and specific meteorological parameters as well as soil and vegetation properties are monitored at the Oensingen site since 2002 (see Ammann et al., 2007). Beginning in 2006, also fluxes and concentrations of main reactive nitrogen species have been measured by various systems, semi-continuously or in campaign mode (see Sect. 2.3).

Here, we report about inter-comparison measurements at the field site during August-October 2006 and October 2007. The first period comprised two grass regrowth phases with leaf area index (LAI) values increasing from about 0.5 to 4 and a harvest (12 September 2006) and succeeding slurry application event (27 September 2006) in between. The second period followed a grass cut on 11 October 2007 and included a slurry application event on 24 October 2007.

\section{2 $\sum \mathrm{N}_{\mathrm{r}}$ flux and concentration measurements}

\subsubsection{System setup}

The total reactive nitrogen converter (TRANC) custom-built according to Marx et al. (2012) was used for fast response detection of $\sum \mathrm{N}_{\mathrm{r}}$. The basic principle of the converter is to thermally convert all reduced and oxygenated $\mathrm{N}_{\mathrm{r}}$ compounds to nitric oxide (NO), which is then analysed by a commercially available NO detector. For this purpose, the sample air 
is first passing an alloy cell heated to $870^{\circ} \mathrm{C}$ followed by a gold cell heated to $300^{\circ} \mathrm{C}$. Between the two cells, $\mathrm{CO}$ is added to the sample air as reducing agent. In the first part, nitrogen containing particles are vapourised and reduced nitrogen gases are oxidized. In the second part, all oxidized $\mathrm{N}_{\mathrm{r}}$ compounds are reduced by $\mathrm{CO}$ to nitric oxide $(\mathrm{NO})$ on the gold catalyst. Once the sample air has passed the converter, only NO is left which does generally not react with the tubing walls. Directly after the converter, a critical orifice restricts the flow to a constant flow rate of $31 \mathrm{~min}^{-1}$ (STP) and produces a strong pressure drop. In this way the residence time is kept small even if the tube between converter and NO analyser is relatively long (see Fig. 1). A detailed description of the converter and tests for its conversion efficiency are given by the companion paper by Marx et al. (2012).

The TRANC was operated in two slightly different versions in 2006 and 2007. In the preliminary version of 2006 the first c. $15 \mathrm{~cm}$ of the steel inlet tube were not actively heated and stayed close to ambient temperature, whereas in the final version (2007) the $1 / 4^{\prime \prime}$ inlet tube was actively heated from the very first millimetre, leading to inner wall temperatures always $>100^{\circ} \mathrm{C}$ (see Marx et al., 2012). The operating temperatures of the alloy $\left(870^{\circ} \mathrm{C}\right)$ and gold tubes $\left(300^{\circ} \mathrm{C}\right)$ in the converter were not affected by this difference. The converter was combined with a fast response chemiluminescence NO analyser (Eco-Physics CLD 780TR, cf. Rummel et al., 2002), which provides a maximum output concentration range of $0 \ldots 500 \mathrm{ppb}$ and an effective response time of $<0.5 \mathrm{~s}$. The fast response time allowed the utilisation of the $\sum \mathrm{N}_{\mathrm{r}}$ detection system (TRANC-CLD) for eddy covariance (EC) flux measurements.

In order to measure the EC flux in the field, the TRANCCLD was used in combination with a 3-dimensional sonic anemometer (Gill Instruments HS Research Anemometer). The analogue output of the CLD $(0 \ldots 10 \mathrm{~V})$ with a time resolution of $0.1 \mathrm{~s}$ was subject to a voltage shift $(-5 \ldots+5 \mathrm{~V})$ and fed into the analogue input of the anemometer where it was digitalised (14 bit) and synchronised with the wind vector data output at a time resolution of $0.05 \mathrm{~s}$. The combined data stream was recorded via serial interface by a computer. In the present study, the EC system was mounted at a height of $1.2 \mathrm{~m}$ above ground (due to the limited field size; see Ammann et al., 2007) near the centre of the experimental grassland field. Since the converter inlet was heated and no additional non-heated inlet tube could be used (due to potential interference of the $\mathrm{N}_{\mathrm{r}}$ compounds with the tube walls), the inlet was positioned at a separation distance of c. $0.30 \mathrm{~m}$ to the sonic anemometer head perpendicular to the two main wind directions and below the anemometer level (see Fig. 1). In this way the wind flow through the anemometer head was not disturbed in most cases and the correlation between the wind signal and the trace gas signal was only moderately attenuated (see results). The CLD for NO detection was positioned in an air-conditioned trailer at $20 \mathrm{~m}$ distance from the actual EC measurement location.

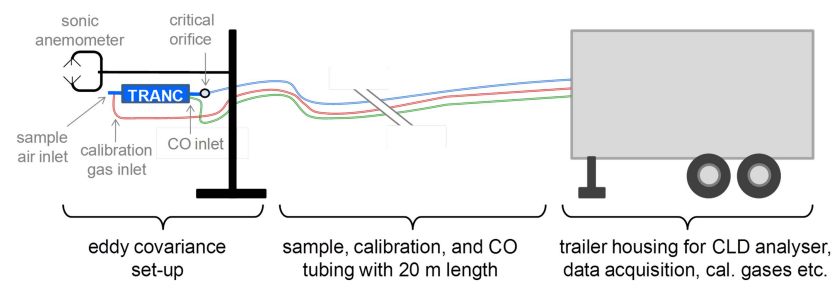

Fig. 1. Schematic overview of the eddy covariance system for $\sum \mathrm{N}_{\mathrm{r}}$ flux measurements at the field site Oensingen. The path of the sample air is indicated in blue, the calibration gas line in red and the CO gas line in green.

The $\sum \mathrm{N}_{\mathrm{r}}$ detection system was regularly calibrated in the field with known $\mathrm{NO}$ and $\mathrm{NO}_{2}$ gas mixtures produced from cylinder standards in combination with an automated gas dilution system. The calibration gas was fed into the system (by switching a solenoid valve) at the TRANC inlet on the field. The sensitivity of the NO analyser showed a minor drift over time of $<20 \%$ in three months and the conversion efficiency for $\mathrm{NO}_{2}$ was always close to $100 \%$ (see also Marx et al., 2012).

\subsubsection{Eddy covariance calculation and corrections}

The EC approach determines the vertical flux of a trace gas in the air as the covariance of the (instantaneous) vertical wind $w$ and the gas concentration $c$ at a given point:

$F_{c}=\sum_{i=1}^{n}[w(t)-\bar{w}] \cdot[c(t+\tau)-\bar{c}]$

$w(t)$ and $c(t)$ are the instantaneous values of vertical wind and scalar concentration (sampling interval $<1 \mathrm{~s}$ ), and the overbars indicate the mean over a suitable flux integration interval. Due to the considerable low-frequent variations of the ambient $\mathrm{N}_{\mathrm{r}}$ concentrations at the field site, the integration interval was set to $10 \mathrm{~min}$, as short as possible for the given measurement height of $1.2 \mathrm{~m}$ without significant flux loss at the low frequent end. The range between about $1 \mathrm{~s}$ and $10 \mathrm{~min}$ covers the time scales of turbulent structures contributing to vertical mixing in the lowest few metres of the atmospheric boundary layer. The time lag $\tau$ is introduced to correct for the delay between sampling and detection/recording of the trace gas concentration due to the residence time in the converter, in the sampling tube, and in the analyser.

The time lag was evaluated empirically as the absolute maximum (peak) of the covariance function within a physically possible range (here $0-6 \mathrm{~s}$ ). The distribution of individual time lags was analysed (see Results section) and found to be fairly constant with time for a given tube length and flow rate. Thus, a default lag time was derived from the empirical distribution for each measurement phase and was used for the final flux calculation. If the location of the covariance function peak was within $\pm 0.5 \mathrm{~s}$ of the default lag, the eddy 
covariance was evaluated with the individual empirical time lag, otherwise the default time lag was used.

Furthermore, the calculation of 10 min average EC fluxes included the following processing steps: (i) before the covariance calculation: despiking, and linear detrending of the raw time series as well as a two-dimensional vector rotation of the wind vector components; (ii) after covariance calculation: calibration and correction for correlated water vapour interference effects. Beside the influence of water vapour on air density fluctuations (WPL effect, Webb et al., 1980), also the interference with the NO detection due to quenching had to be considered. For the NO analyser used here, Marx (2004) determined a $0.19 \%$ NO sensitivity reduction per $1 \mathrm{mmol} \mathrm{mol}{ }^{-1}$ water vapour increase. The corresponding flux interference effect has a very similar behaviour like the WPL effect (same sign, proportional to $\mathrm{N}_{\mathrm{r}}$ concentration and to the water vapour flux), but is about two times larger. In absolute terms, the sum of both $\mathrm{H}_{2} \mathrm{O}$ related corrections is small, but cannot generally be neglected. For a typical background $\sum \mathrm{N}_{\mathrm{r}}$ concentration of $20 \mathrm{ppb}$ and a maximum daytime $\mathrm{H}_{2} \mathrm{O}$ flux of about $5 \mathrm{mmol} \mathrm{m}^{-2} \mathrm{~s}^{-1}$ during the present study, the correction of the $\sum \mathrm{N}_{\mathrm{r}}$ flux amounts to $+4.1 \mathrm{ng}$ $\mathrm{N} \mathrm{m}^{-2} \mathrm{~s}^{-1}$.

The fluxes were also corrected for high-frequency attenuation effects with the empirical ogive method (for details see Sect. 3.2) and were subjected to a quality selection using the stationarity criterion after Foken and Wichura (1996). Finally, the 10-min values for fluxes and concentrations were aggregated to half-hourly means for comparison with other measurements.

\subsection{Flux and concentration measurements of individual $\mathrm{N}_{\mathrm{r}}$ compounds}

As part of the NitroEurope experimental network to assess the total Nitrogen budget of European ecosystems, several measurement systems for individual gaseous $\mathrm{N}_{\mathrm{r}}$ compounds have been operated for extended periods at the Oensingen site. Among these are a dynamic chamber system for $\mathrm{NO}$ and $\mathrm{NO}_{2}$ (Sect. 2.3.1) and a gradient system for $\mathrm{NH}_{3}$ (Sect. 2.3.2). Only for an intensive observation period of a few weeks in summer 2006, the GRAEGOR system for additional concentration measurements of the inorganic water soluble gases $\mathrm{NH}_{3}, \mathrm{HONO}, \mathrm{HNO}_{3}$ and their related aerosol compounds $\mathrm{NH}_{4}^{+}, \mathrm{NO}_{3}^{-}$(Thomas et al., 2009; Wolff et al., 2010) was operated at the site (see also Marx et al., 2012). The general availability of concentration and flux measurements during the two study periods is summarised in Table 1 .

\subsubsection{Dynamic chamber measurements of $\mathrm{NO}$ and $\mathrm{NO}_{2}$}

A dynamic chamber system for the measurement of $\mathrm{NO}$ and $\mathrm{NO}_{2}$ fluxes and concentrations was operated continuously (half hour resolution) and consisted of 3-5 automated chambers. $\mathrm{NO}_{2}$ and $\mathrm{NO}$ (and $\mathrm{O}_{3}$ ) concentrations were detected inside and outside the chambers by a chemiluminescence detector (ThermoEnvironment $42 \mathrm{C}$ trace level) in combination with an photolytic "bluelight" converter (see e.g., Pollack et al., 2010). The detailed chamber system design and the general data processing is described in Pape et al. (2009). As main quality control measure, cases with highly nonstationary ambient concentrations were rejected. Due to the modified air exchange within the dynamic chambers and with the ambient air, the chamber flux was corrected for the turbulent transport (aerodynamic and boundary layer resistances) in undisturbed ambient conditions using turbulence characteristics obtained from EC measurements. Finally the flux results of the parallel chambers were averaged to half-hourly or hourly means.

For the last observation period in October 2007, no chamber flux measurements were available. Therefore, the $\mathrm{NO}_{2}$ deposition flux was derived by an inferential approach (e.g., Hicks et al., 1987) using the measured ambient concentration $c_{\mathrm{NO}_{2}}$ and the aerodynamic resistances $R_{a}$ and $R_{b}$ in combination with a parameterised surface resistance $R_{c}$ for $\mathrm{NO}_{2}$ deposition:

$F_{\mathrm{NO}_{2}, \text { inf }}=-v_{\mathrm{d}} \cdot c_{\mathrm{NO}_{2}}=-\left(R_{a}+R_{b}+R_{c, \text { param }}\right)^{-1} \cdot c_{\mathrm{NO}_{2}}$

The parameterisation for $R_{c}$ was derived from the qualityselected $\mathrm{NO}_{2}$ chamber flux measurements of the preceding period August-October 2006 on the same field. $R_{c}$ values were calculated from the fluxes (see Pape et al., 2009) and a nonlinear parameterisation scheme as a function of canopy height $h_{\text {can }}$ and global radiation gRad was fitted to the data:

$\frac{1}{R_{c, \text { param }}}=G_{c, \max }\left(h_{\text {can }}\right) \cdot\left[\gamma_{\text {night }}+f_{\text {light }}(\mathrm{gRad})\right]$

with $G_{c, \text { max }}$ denoting the light-saturated surface conductance as a function of the canopy height, $\gamma_{\text {night }}$ a coefficient for light-independent (nighttime) deposition and $f_{\text {light }}$ a hyperbolic function of the global radiation.

\subsubsection{Gradient measurements of $\mathrm{NH}_{3}$}

Ammonia concentrations and fluxes have been measured with a gradient system described by Spirig et al. (2010). The system consists of two AiRRmonia analysers (Mechatronics, Hoorn, NL). Two sample blocks with gas-permeable membranes are installed at two heights (ca. $0.4 \mathrm{~m}$ and $1.4 \mathrm{~m}$ above the surface). $\mathrm{NH}_{3}$ is scrubbed from the air by diffusion through the membrane into a counter-flowing stream of a slightly acidic stripping solution. The latter is conducted to detector blocks where ammonium is detected by means of conductivity measurements. The stripping solutions of the two profile levels where regularly switched between two detector blocks to avoid systematic offsets in the detection of the vertical gradient.

The system was operated semi-continuously $(30 \mathrm{~min}$ resolution) from spring to fall and $\mathrm{NH}_{3}$ fluxes were calculated 
Table 1. Overview of the used concentration and flux measurement systems for nitrogenous compounds and their availability during the two study periods.

\begin{tabular}{|c|c|c|c|c|}
\hline \multirow[t]{2}{*}{ quantity } & \multirow[t]{2}{*}{ analyser } & \multirow[t]{2}{*}{ flux method } & \multicolumn{2}{|c|}{ availability } \\
\hline & & & 2006 & 2007 \\
\hline$\sum \mathrm{N}_{\mathrm{r}}$ & $\begin{array}{l}\text { Ecophysics } \\
\text { CLD + TRANC }\end{array}$ & eddy covariance & $\begin{array}{l}\text { conc. + flux } \\
\text { (prelim. TRANC) }\end{array}$ & $\begin{array}{l}\text { conc. }+ \text { flux } \\
\text { (final TRANC) }\end{array}$ \\
\hline NO & TEI CLD & dynamic chamber & conc. + flux & conc. \\
\hline $\mathrm{NO}_{2}$ & $\begin{array}{l}\text { TEI CLD } \\
+ \text { bluelight conv. }\end{array}$ & dynamic chamber & conc. + flux & $\begin{array}{l}\text { conc. + inferred } \\
\text { flux }^{\mathrm{b}}\end{array}$ \\
\hline $\mathrm{NH}_{3}$ & AiRRmonia & gradient & conc. + flux & conc. + flux \\
\hline $\mathrm{NH}_{3}, p \mathrm{NH}_{4}^{+}$ & GRAEGOR & - & conc. $^{\mathrm{a}}$ & - \\
\hline $\mathrm{HNO}_{3}, p \mathrm{NO}_{3}^{-}$ & GRAEGOR & - & conc. $^{\mathrm{a}}$ & - \\
\hline HONO & GRAEGOR & - & conc. $^{\mathrm{a}}$ & - \\
\hline
\end{tabular}

by the aerodynamic flux-gradient method (see Spirig et al., 2010; Flechard et al., 2010). The average accuracy of the $\mathrm{NH}_{3}$ flux measurements during unstable and near-neutral conditions was estimated to $20 \%$ and the detection limit to $8 n g-\mathrm{N} \mathrm{m}^{-2} \mathrm{~s}^{-1}$.

\section{Results}

\subsection{Concentration measurements and inter-comparison}

During August 2006 the largest set of individual $\mathrm{N}_{\mathrm{r}}$ species concentration measurements was operated at the Oensingen field site (see Table 1). This was a period without fertiliser application and other management activities on the field. An overview of the measured concentration ranges (with median and quartiles) and the mean relative contribution of the individual compounds to $\sum \mathrm{N}_{\mathrm{r}}$ is given in Fig. 2. It shows that $\mathrm{NO}, \mathrm{NO}_{2}$ and $\mathrm{NH}_{3}$ constitute the most important compounds (together contributing 85-90\%) with concentrations typically between $1 \mathrm{ppb}$ and $10 \mathrm{ppb}$. This may be explained by the strong anthropogenic emission sources with intense traffic (nearby national highway) and agriculture in this region. The other observed $\mathrm{N}_{\mathrm{r}}$ compounds (gaseous and particulate) showed concentrations mostly below $1 \mathrm{ppb}$ and together only contributed about $10 \%$ to $\sum \mathrm{N}_{\mathrm{r}}$. Especially $\mathrm{HNO}_{3}$ is very low compared to $\mathrm{NO}_{\mathrm{x}}$ indicating a low photochemical age of the air mass and, thus, a short distance to $\mathrm{N}_{\mathrm{r}}$ emission sources. The concentration of NO was more variable than that of the other compounds and strongly depended on the ozone concentration, which itself varied with time of day and weather conditions. Due to the nearby emission sources the (advected) $\mathrm{NO}, \mathrm{NO}_{2}$ and $\mathrm{NH}_{3}$ concentrations showed a high variability on various time scales from several days down to minutes. Detailed examples of concentration time series are shown below (Sect. 3.3) in direct connection with the flux measurements.
After August 2006, only a reduced set of component specific measurements for the main $\mathrm{N}_{\mathrm{r}}$ components $\mathrm{NO}, \mathrm{NO}_{2}$ and $\mathrm{NH}_{3}$ was operated in parallel to the TRANC-CLD system (cf. Table 1). As shown in Fig. 2b the mean contribution of the three species to the $\sum \mathrm{N}_{\mathrm{r}}$ concentration (by TRANCCLD) is generally between $80-90 \%$ for all observation periods.

Figure 3 shows a typical $24 \mathrm{~h}$ period of $\sum \mathrm{N}_{\mathrm{r}}$ concentrations with a 2 -min time resolution at the measurement site illustrating the strong concentration variability in the time scales of several minutes to hours. The comparison with the course of the meteorological parameters (half-hourly means) shows that some variations may be attributed to changes in wind speed, wind direction or atmospheric stability driven by the radiation. However, even in conditions with persisting meteorological conditions, the $\sum \mathrm{N}_{\mathrm{r}}$ concentration could vary due to the influence of advected (meandering) plumes of nearby anthropogenic sources.

\subsection{Response characteristics and correction of the $\mathrm{EC}$ fluxes}

A necessary prerequisite of successful EC flux measurements is that the covariance between $w$ and $c$ (Eq. 1) is significant, i.e., that it can be clearly discerned from the noise in the covariance. This can be checked by the cross-covariance function. It corresponds to the covariance flux in Eq. (1) evaluated for varying values of the lag time $\tau$. Two examples for such functions are plotted in Fig. 4. The left case shows clear positive covariance peaks both for temperature $T$ (at $\tau=0$ ) and $\sum \mathrm{N}_{\mathrm{r}}$ concentration (at $\tau=1.95 \mathrm{~s}$ ). The observed lag time corresponds to a plausible value of the residence time in the converter, sampling tube and detector cell for the given volume, pressure and air flow values. The slender shape of the covariance peaks indicates a major contribution of high frequencies to the flux. The second case represents a nighttime 

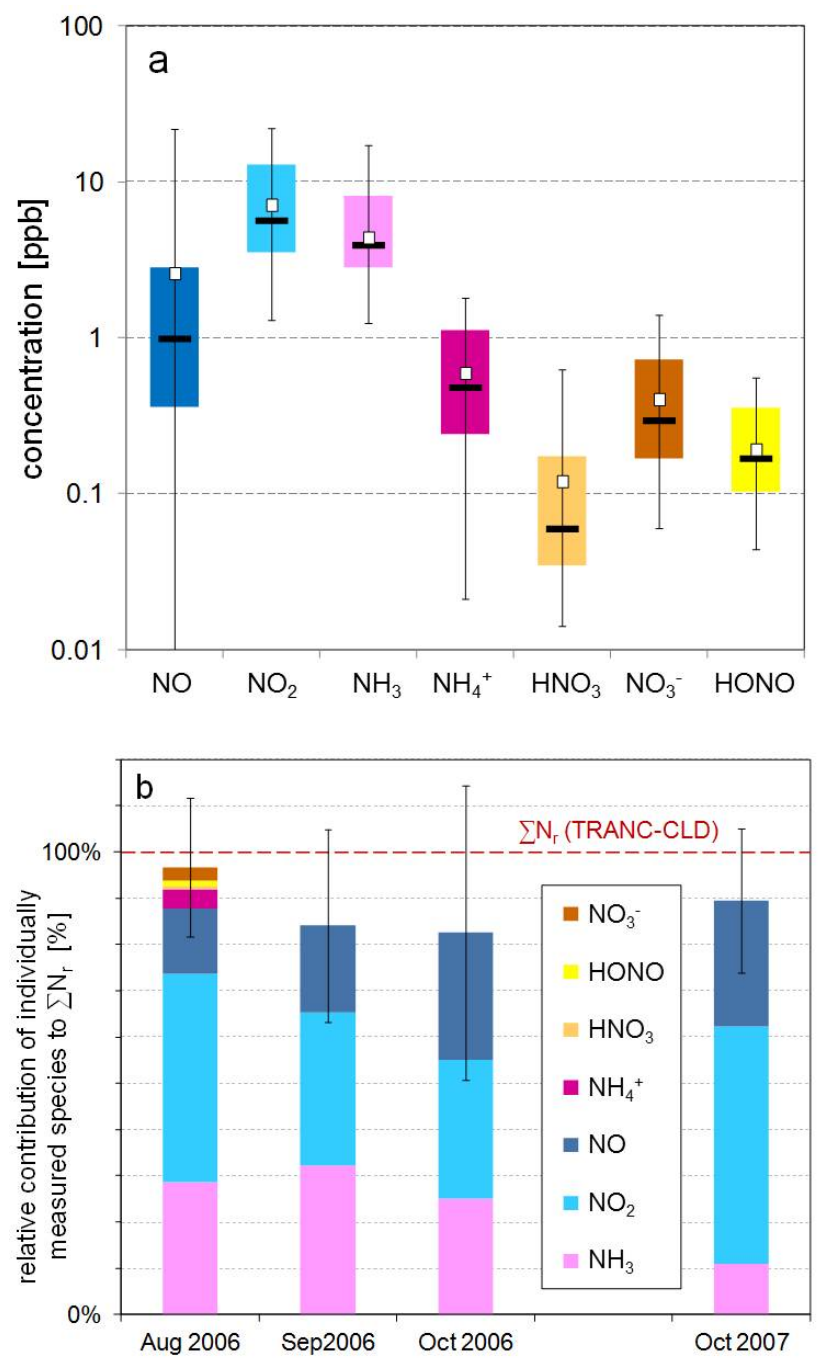

Fig. 2. Statistical results for $\mathrm{N}_{\mathrm{r}}$ species composition measurements at the Oensingen field site. (a) Box-plots of half-hourly concentration measurements of various $\mathrm{N}_{\mathrm{r}}$ compounds during August 2006 (only cases included with all individual concentration measurements available, $n=287$ ); open squares: arithmetic averages; horizontal bars: medians; vertical lines: range between $1 \%$ and $99 \%$ quantiles; coloured boxes: inter-quartile ranges. (b) Mean relative contribution of individual $\mathrm{N}_{\mathrm{r}}$ compounds to the $\sum \mathrm{N}_{\mathrm{r}}$ concentration observed by the TRANC-CLD system $(=100 \%)$ for different operation periods in 2006 and 2007. Note that measurements of the minor compounds $\mathrm{NO}_{3}^{-}, \mathrm{HONO}, \mathrm{HNO}_{3}$ and $\mathrm{NH}_{4}^{+}$were only available in August 2006. Black vertical bars indicate the standard deviation of the relative cumulated contribution of half-hourly measurements.

situation with stable conditions. While the covariance function for temperature still shows a single well defined peak, the covariance function for $\sum \mathrm{N}_{\mathrm{r}}$ is much more noisy and the small peak at $\tau=1.9 \mathrm{~s}$ tends to be masked by the other fluctuations. The noise in the covariance function is obviously caused by non-stationarity of the $\sum \mathrm{N}_{\mathrm{r}}$ concentration time series.

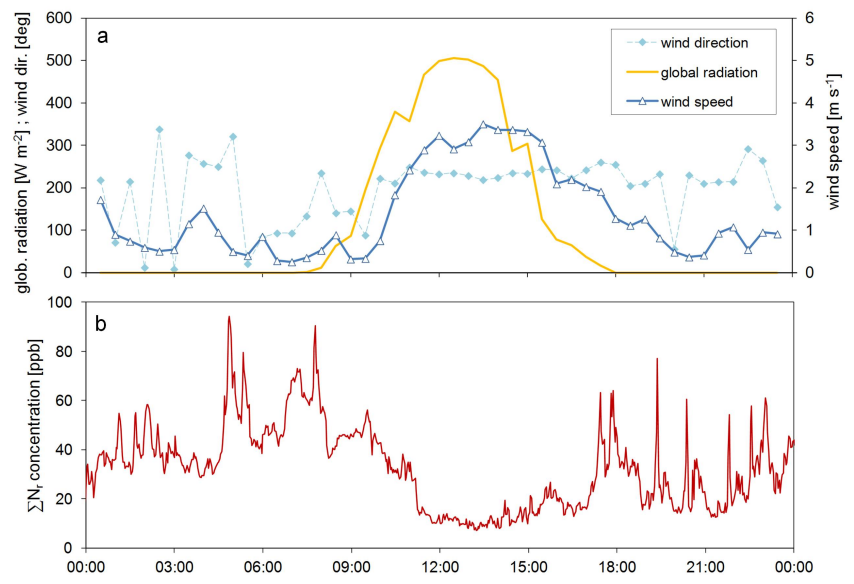

Fig. 3. Exemplary $24 \mathrm{~h}$ time series of (a) meteorological parameters (half-hourly means) and (b) $\sum \mathrm{N}_{\mathrm{r}}$ concentration ( 2 min means) measured by the TRANC-CLD system for the 20 October 2006 at the Oensingen field site (no rain on this day).
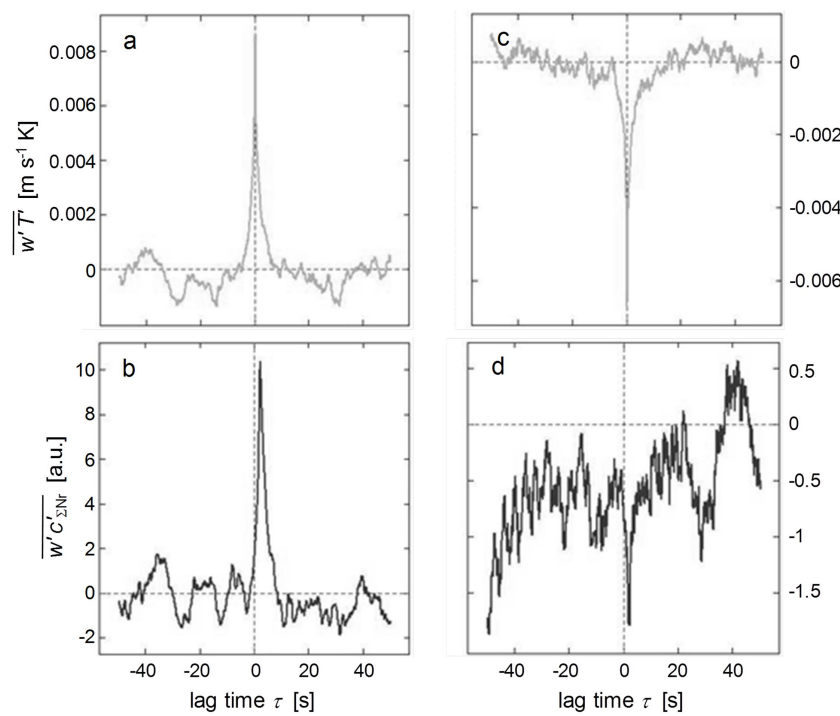

Fig. 4. Exemplary cross-covariance functions of vertical wind speed with temperature $(\mathbf{a}, \mathbf{c})$ and $\sum \mathrm{N}_{\mathrm{r}}$ concentration $(\mathbf{b}, \mathbf{d})$ obtained by the TRANC-CLD EC system at the Oensingen site. The left side (a, b) shows a daytime emission case after a slurry application event (26 October 2007 10:00); the right side (c, d) shows a nighttime deposition case before the slurry application event (23 October 2007 04:00).

Figure 5 shows the statistical distributions of the lag times within the physically plausible range for the two observation periods in 2006 and 2007 determined as described in Sect. 2.2.2. For 2006, a longer sampling tube had been used leading to a significantly longer residence time of the sample air in the system. The peak central positions $\tau=2.6 \mathrm{~s}$ (2006) and $\tau=1.95 \mathrm{~s}$ (2007) were considered as default time lags for the EC flux evaluation (see Sect. 2.2.2). 


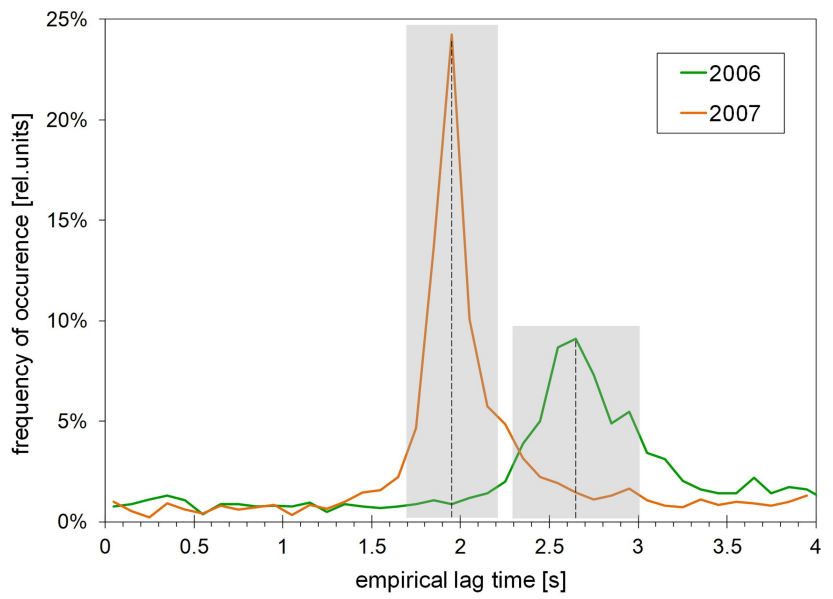

Fig. 5. Frequency distribution of empirical lag times detected as peak (absolute maximum or minimum) of the covariance function between $w$ and $c_{\Sigma \mathrm{N}_{\mathrm{r}}}$ (see Fig. 4). Maxima of the histograms marked by dashed lines are used as default lag times for the period. For cases with a detected lag time within the gray range, the peak covariance was used for the flux calculation, in all other cases the flux was evaluated at the default lag time.

Despite a significant peak in the covariance function, some high frequency damping of the TRANC derived $\sum \mathrm{N}_{\mathrm{r}}$ time series is likely to occur due to mixing effects during the sampling air flow through the converter and the tube. The total damping effect was determined empirically with the ogive method according to Ammann et al. (2006). An exemplary case of this method is illustrated in Fig. 6. The ogive (cumulative cospectrum) of the $\sum \mathrm{N}_{\mathrm{r}}$ flux is scaled to the corresponding sensible heat flux ogive (used as reference) in the medium-low frequency range, where no damping is supposed to occur. The resulting deviation of the trace gas ogive from the reference ogive at the high frequency end is a quantitative measure of the spectral damping. In the present case, the $\sum \mathrm{N}_{\mathrm{r}}$ ogive indicates a damping factor of 0.78 (loss of $22 \%$ of the flux). Overall only a slight dependence of the damping factor on horizontal wind speed was found (Fig. 7), with median values between 0.81 (near zero wind speed) and 0.74 (around $4 \mathrm{~m} \mathrm{~s}^{-1}$ wind speed). This dependence could be described with the displayed linear function that was used for correction of the $\sum \mathrm{N}_{\mathrm{r}}$ fluxes. The same dependence on wind speed was found for the 2006 data. A potential additional dependence on stability was also analysed, but no significant effect was found. Yet this analysis did not cover very stable conditions, for which not enough data remained after quality selection.

\subsection{Comparison of flux measurements}

In this section, selected time series of concentration and flux measurements by the TRANC-CLD system are shown in comparison to other available measurements at the field

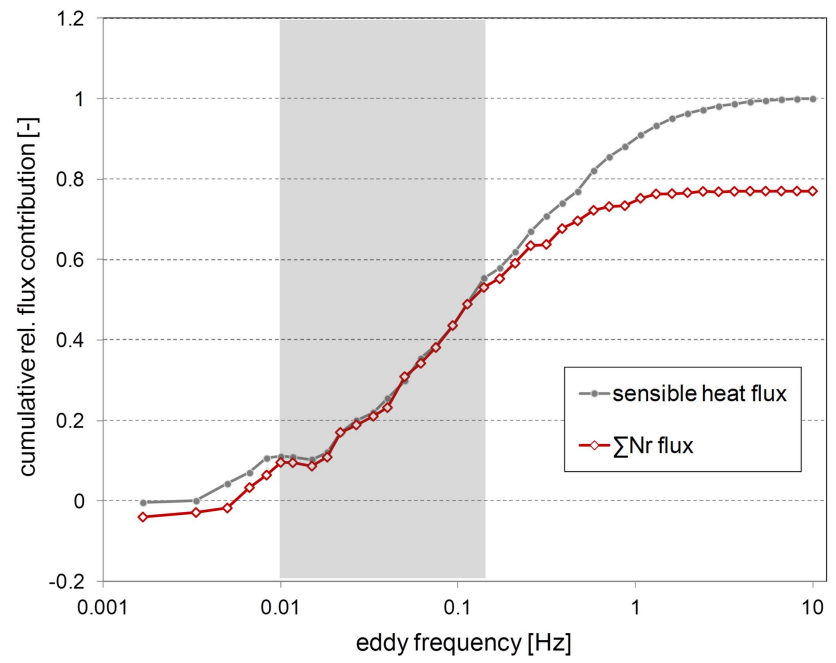

Fig. 6. Exemplary case of normalised flux ogives (= cumulative cospetra) for the sensible heat flux and the $\sum \mathrm{N}_{\mathrm{r}}$ flux at the Oensingen site. The sensible heat flux ogive was normalised to 1 and the trace gas ogive was scaled to the sensible heat ogive in the mediumlow frequency range (gray shaded area). The cumulative value at the right end of the curves indicates the high frequency damping factor.

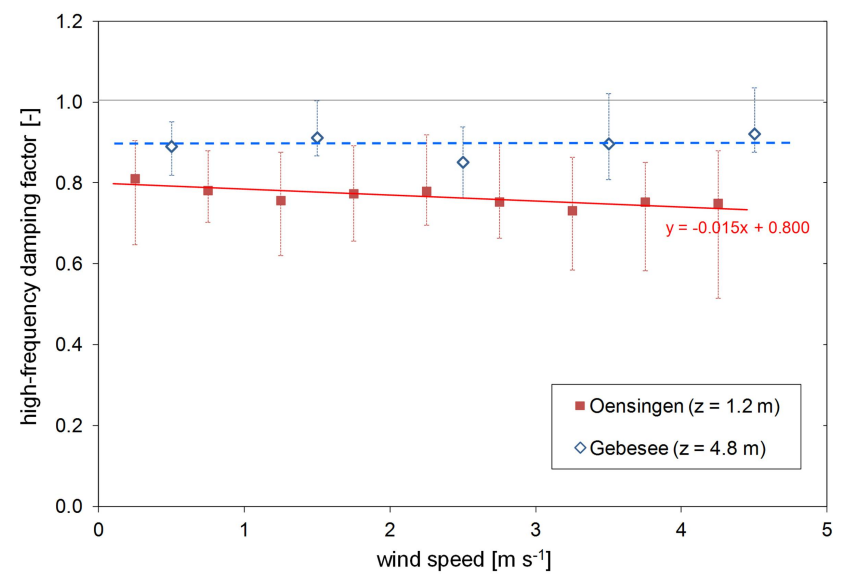

Fig. 7. Median and inter-quartile range of high-frequency damping factors for the $\sum \mathrm{N}_{\mathrm{r}}$ flux by TRANC-CLD as a function of horizontal wind speed. Red solid squares represent results from the Oensingen grassland site (October 2007) with a low measurement height of $1.2 \mathrm{~m}$. For comparison purposes, the blue open diamonds show corresponding results from the Gebesee arable site (June-July 2008) with a considerably larger measurement height of $4.8 \mathrm{~m}$. The thick solid and dashed lines show linear regression functions of the median values. For Oensingen, the slope of the regression line was statistically significant with a $95 \%$ confidence interval of $-0.015 \pm 0.009\left(\mathrm{~m} \mathrm{~s}^{-1}\right)$. Data for the damping analysis were selected for significant peaks in the covariance function at a plausible delay time and for near-stationary conditions (small flux contributions at the low-frequent end of the cospectrum/ogive). 

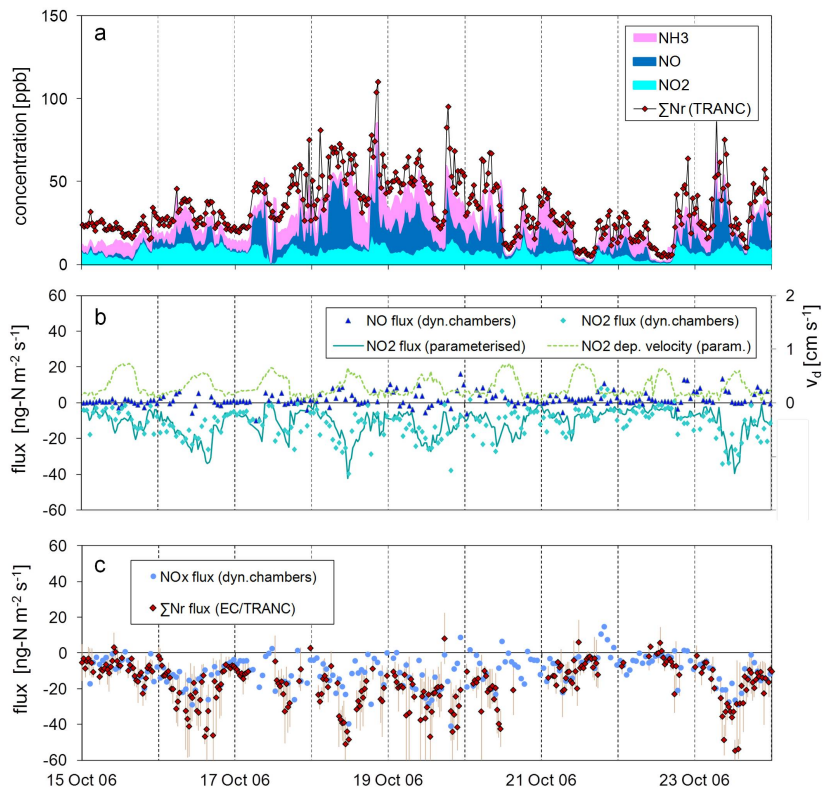

Fig. 8. Nine days of half-hourly concentration and flux data at the Oensingen grassland site during a growing phase in autumn 2006. (a) $\sum \mathrm{N}_{\mathrm{r}}$ and individual compound concentrations; (b) $\mathrm{NO}$ and $\mathrm{NO}_{2}$ fluxes measured by the dynamic chamber system, and $\mathrm{NO}_{2}$ flux and deposition velocity estimated by the inferential method using a parameterised surface resistance fitted to the measured fluxes; (c) $\mathrm{NO}_{\mathrm{X}}$ fluxes obtained by the dynamic chamber system and $\sum \mathrm{N}_{\mathrm{r}}$ fluxes obtained by EC measurements with the preliminary TRANC version (see also Table 1). Vertical error bars were determined from sub-interval flux variability.

site (see Table 1). The chosen time periods of 7-11 days length were selected for data availability and specific events (slurry applications). First, results from September and October 2006 using the preliminary converter version are presented.

Figure 8 shows field data near the end of a grass growing phase with a LAI of 3 to 4 . The concentration results show that the three main compounds $\mathrm{NO}, \mathrm{NO}_{2}$, and $\mathrm{NH}_{3}$ accounted for large parts of $\sum \mathrm{N}_{\mathrm{r}}$. The temporal variability of $\sum \mathrm{N}_{\mathrm{r}}$ was caused mainly by fluctuations of the NO concentration with lowest values in the afternoon. $\sum \mathrm{N}_{\mathrm{r}}$ measured by TRANC-CLD showed on average slightly higher values than the sum of the three individual compounds - as expected due to the potential contribution of the residual $\mathrm{N}_{\mathrm{r}}$ compounds (see Fig. 2) - but with a very good agreement in the temporal course. The observed EC fluxes of $\sum \mathrm{N}_{\mathrm{r}}$ were generally negative during this period indicating an overall deposition of $\mathrm{N}_{\mathrm{r}}$ with relatively high values during daytime and low values in the night. The sign of the flux as well as its magnitude range and temporal variation is in fair agreement with the parallel measurements of the $\mathrm{NO}_{\mathrm{x}}$ flux by dynamic chambers (no continuous $\mathrm{NH}_{3}$ flux measurement of sufficient quality was available for this period). The vertical error bars show the flux uncertainty due to non-stationarity

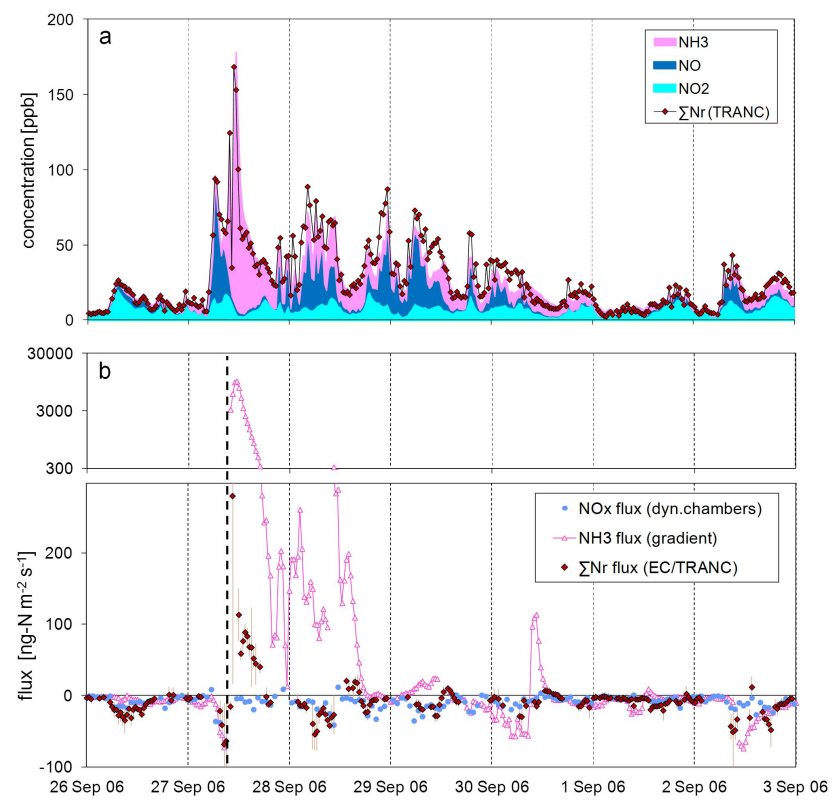

Fig. 9. Six days of (a) concentration and (b) flux measurements at the Oensingen grassland site around a slurry application event (vertical dashed line) in autumn 2006. $\sum \mathrm{N}_{\mathrm{r}}$ concentrations and fluxes result from EC measurements with the preliminary TRANC version (vertical error bars determined from sub-interval flux variability). $\mathrm{NO}$ and $\mathrm{NO}_{2}$ concentrations and $\mathrm{NO}_{\mathrm{x}}$ fluxes result from the slow response TEI analyser in combination with the dynamic chamber system. $\mathrm{NH}_{3}$ concentration and fluxes result from the AiRRmonia gradient system (see also Table 1).

as determined from the sub-interval flux variability similar to the concept by Foken and Wichura (1996). Extreme cases (outliers) have been removed by the applied stationarity test. The $\mathrm{NO}_{\mathrm{x}}$ flux (lowest panel) itself was strongly dominated by $\mathrm{NO}_{2}$ deposition with only small and rather noise-like contributions of $\mathrm{NO}$ emission (middle panel). The observed $\mathrm{NO}_{2}$ deposition could be well described by the inferential parameterisation presented in Eqs. (2) and (3) with the deposition velocity being a function of the turbulence intensity, the global radiation and the grass canopy height. The diurnal variation of the deposition fluxes was not well correlated with the corresponding concentrations, which indicates that it was mainly limited by the deposition velocity.

A partly contrasting observation period around a slurry application event is displayed in Fig. 9. While directly after the slurry application on 27 September 2006 the $\sum \mathrm{N}_{\mathrm{r}}$ concentration was dominated by $\mathrm{NH}_{3}$, its contribution decreased to very low values in the following days. As expected a very strong emission of $\mathrm{NH}_{3}$ was observed by the gradient system after the slurry spreading. It varied (declined) over 2-3 orders of magnitude within two days. However, the EC flux with the preliminary TRANC version did not show the huge contribution of the $\mathrm{NH}_{3}$ emission. Instead, it largely followed the $\mathrm{NO}_{\mathrm{X}}$ chamber flux with only a very minor emission phase 
directly after slurry application. This emission is about two orders of magnitude lower than the $\mathrm{NH}_{3}$ emission observed by the gradient system, indicating that the EC system with the preliminary converter version was not able to measure $\mathrm{NH}_{3}$ exchange correctly.

The final converter version was operated in the EC setup at the field site in October 2007. This period included a slurry application event on the fourth day (Fig. 10). Before this event and about 5 days afterwards, the $\sum \mathrm{N}_{\mathrm{r}}$ concentration was strongly dominated by $\mathrm{NO}_{\mathrm{x}}$. However, after slurry spreading, the $\sum \mathrm{N}_{\mathrm{r}}$ concentration jumped to much higher values dominated by $\mathrm{NH}_{3}$ emitted from the fertilised field. Directly after slurry spreading (10:00 local time) the concentration was frequently above the detection range of the analyser and, therefore, the sample air was diluted by about a factor of two by adding $1.41 \mathrm{~min}^{-1}$ synthetic air into the total sample flow of $31 \mathrm{~min}^{-1}$ In this way the concentration range of the analyser could be nearly doubled. This was done for about three hours, after which the $\sum \mathrm{N}_{\mathrm{r}}$ concentration had dropped again to within the normal measurement range. Generally, the $\mathrm{NH}_{3}$ concentration and the corresponding $\sum \mathrm{N}_{\mathrm{r}}$ concentration and flux showed a quasi exponential decrease with time after the slurry application.

Unfortunately no flux results from the $\mathrm{NH}_{3}$ gradient system are available for the $24 \mathrm{~h}$ after the slurry application, due to the failure of one of the two measurement levels. The flux inter-comparison in Fig. 10 shows a good agreement between the $\sum \mathrm{N}_{\mathrm{r}}$ fluxes and the gradient derived $\mathrm{NH}_{3}$ fluxes for the days after the slurry application. During this phase, the $\mathrm{NO}_{2}$ deposition flux was much smaller and played an almost negligible role for the $\sum \mathrm{N}_{\mathrm{r}}$ exchange.

\section{Discussion}

\subsection{Concentration measurements and $\mathrm{N}_{\mathrm{r}}$ species composition at the field site}

The presented field measurements comprised a wide range of $\sum \mathrm{N}_{\mathrm{r}}$ concentrations ( $<1$ to $350 \mathrm{ppb}$ ) with strongly variable contributions of the three main compounds $\mathrm{NO}, \mathrm{NO}_{2}$ and $\mathrm{NH}_{3}$. The comparison of measured concentrations (absolute values and temporal course) in Figs. 2 and 8-10 indicate near-complete conversion (recovery) of these three main compounds by the TRANC-CLD system within the range of uncertainties. The residual $\sum \mathrm{N}_{\mathrm{r}}$ concentration (10-15\%) can be attributed to a large part to other minor inorganic gaseous and particulate compounds as shown by the additional species measurements at the field site in August 2006 (Fig. 2b, left column; see also Marx et al., 2012). Organic compounds not individually measured at the site (e.g., peroxy and alkyl nitrates) most likely contribute only a few percent to the detected $\sum \mathrm{N}_{\mathrm{r}}$ (Clemitshaw, 2004). Steinbacher et al. (2007) showed that the concentration of the most abundant organic $\mathrm{N}_{\mathrm{r}}$ compound peroxy-acetylnitrate (PAN) is
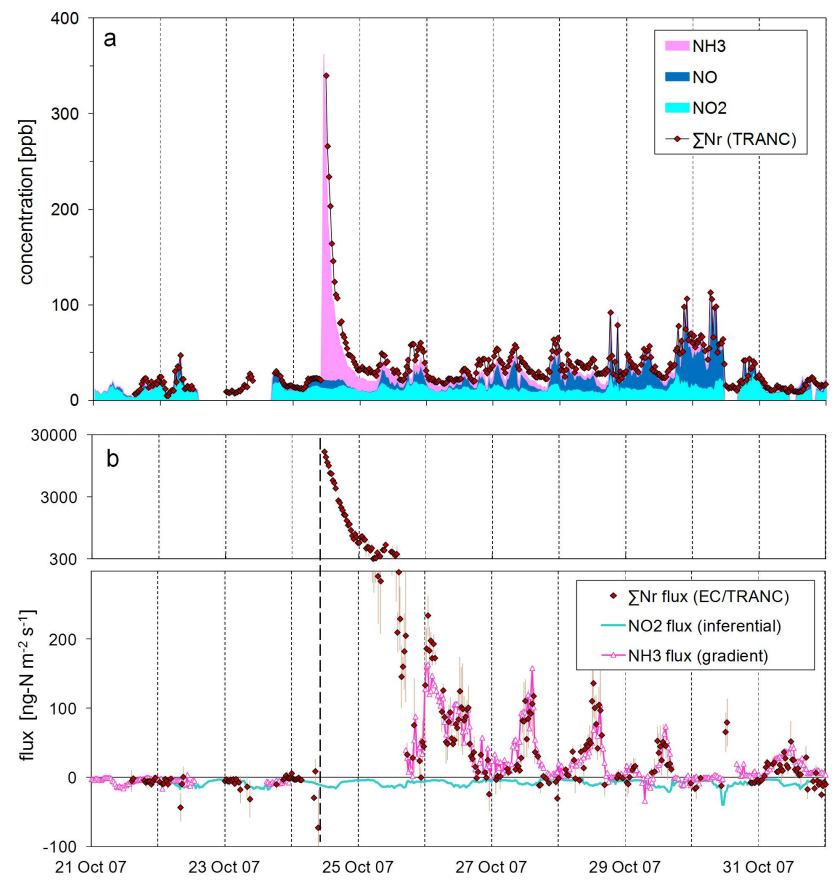

Fig. 10. Ten days of (a) concentration and (b) flux measurements at the Oensingen grassland site around a slurry application event (vertical dashed line) in autumn 2007. $\sum \mathrm{N}_{\mathrm{r}}$ concentrations and fluxes result from the EC measurements using the final TRANC version (vertical error bars determined from sub-interval flux variability). $\mathrm{NO}$ and $\mathrm{NO}_{2}$ concentrations result from the slow response TEI analyser, and the $\mathrm{NO}_{2}$ fluxes were inferred from measured concentrations and the resistance parameterisation derived from dynamic chamber fluxes in preceding periods. $\mathrm{NH}_{3}$ concentration and fluxes result from the AiRRmonia gradient system (see also Table 1). In (a), individual concentrations of $\mathrm{NO}, \mathrm{NO}_{2}$ and $\mathrm{NH}_{3}$ are shown only for cases when data for all three compounds were available.

generally below $1 \mathrm{ppb}$ in a region with similar intensive agriculture in the eastern part of the Central Swiss Plateau.

The individual conversion efficiencies of the system for the main gaseous and some particulate $\mathrm{N}_{\mathrm{r}}$ compounds has also been investigated by laboratory experiments reported in Marx et al. (2012) and were found to be not significantly different from $100 \%$. In addition, there is clear evidence from previous published studies (e.g., Fahey et al., 1985; McCalley and Sparks, 2008) about the near-total conversion of the individual oxidized species $\mathrm{NO}_{2}, \mathrm{HONO}, \mathrm{HNO}_{3}$ and PAN, in gold catalyst converters comparable to the reducing unit of the TRANC. From the results of this study in combination with the laboratory tests presented in Marx et al. (2012) and corresponding findings on thermal nitrogen conversion reported in the literature, we, thus, infer a near-complete conversion of all airborne reactive nitrogen compounds by the TRANC.

The uncertainty of the $\sum \mathrm{N}_{\mathrm{r}}$ concentration measurement by the TRANC-CLD system is also slightly affected by the offset signal of the CLD analyser (dark counts of 
photomultiplier and possible slow chemiluminescent reactions of molecules other than NO). For this instrument, the offset is usually quantified by regular directing the sample air through a time buffering "pre-chamber" before chemiluminescence detection. However, in the present case, the prechamber was not used in order to get a fully continuous fast response concentration time series. Instead, the offset signal was determined by calibration with zero air every $4-5$ days during the field campaigns. It was found relatively small at an apparent concentration of $1.5 \pm 0.5 \mathrm{ppb}$. The mean value was used for offset correction of the measurement signals. It has to be noted that the potential error of the offset correction has no influence on the EC flux calculation, since in Eq. (1) the mean quantities are determined and subtracted individually for each averaging interval. The problem with the CLD offset signal may be solved in the future by regular pre-chamber measurements. For this purpose a digital data sampling and control of the CLD is necessary, requiring a more sophisticated EC data acquisition software. The automated regular switching to pre-chamber mode (e.g., for five minutes every hour) will produce only a small gap in the time series that can be dealt with in the EC flux calculation.

The monthly mean concentration values in Fig. 2 can be compared to corresponding observations for the same month at the national air pollution monitoring station Payerne (BAFU, 2008), located about $85 \mathrm{~km}$ southwest of Oensingen also in a region with intensive agriculture. The monthly means in Payerne were: $0.6 \mathrm{ppb} \mathrm{NO}, 4.0 \mathrm{ppb} \mathrm{NO}_{2}$, $5.0 \mathrm{ppb}\left(\mathrm{NH}_{3}+\mathrm{NH}_{4}^{+}\right)$, and $0.7 \mathrm{ppb}\left(\mathrm{HNO}_{3}+\mathrm{NO}_{3}^{-}\right)$. Thus, while the latter two concentration sums were very similar for both sites, $\mathrm{NO}$ and $\mathrm{NO}_{2}$ was lower at Payerne (being more comparable to the lower quartiles of the Oensingen results in Fig. 2. This may be explained by the more intense car traffic source around the Oensingen site.

In general, the observed $\mathrm{N}_{\mathrm{r}}$ concentrations were mostly the result of advection and hardly influenced by the experimental field itself, although local deposition can slightly lower the concentrations at the measurement height. A clear exception in this respect is the $\mathrm{NH}_{3}$ concentration during and after slurry application (see Figs. 9 and 10). The huge step-like increase and the exponential decrease of the concentration can be considered as roughly proportional to the respective volatilisation source of the spread slurry on the field (Sintermann et al., 2011). The magnitude of the concentration peak and the temporal course of the decrease is well comparable to the observation by Spirig et al. (2010) and Sintermann et al. (2011) for other slurry events at the same site. In contrast to $\mathrm{NH}_{3}$, the $\mathrm{NO}$ concentration is hardly influenced by local soil emission, which was found generally very small.

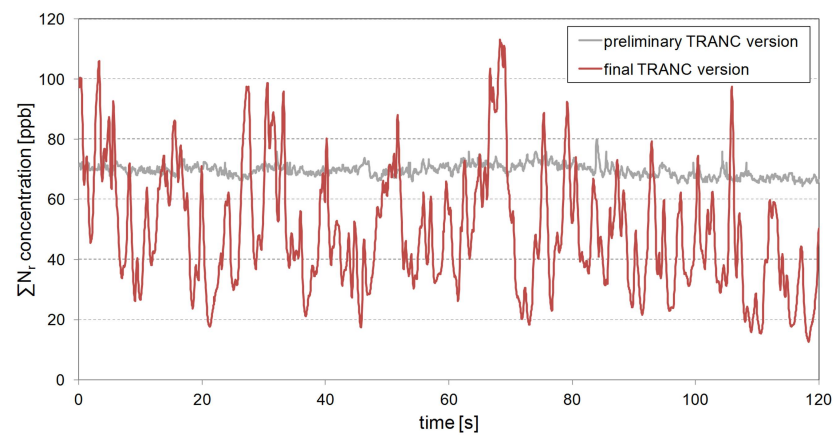

Fig. 11. High-resolution time series $(20 \mathrm{~Hz})$ of $\sum \mathrm{N}_{\mathrm{r}}$ concentration detected shortly after two slurry application events with the preliminary (27.9.2006 11:20) and the final TRANC version (24.10.2007 12:00), respectively. For both periods, a strong $\mathrm{NH}_{3}$ emission in the same order of magnitude (around $10000 \mathrm{ng}-\mathrm{N} \mathrm{m}^{-2} \mathrm{~s}^{-1}$ ) is assumed (see Figs. 9 and 10).

\subsection{Performance of TRANC-CLD system for eddy covariance}

\subsubsection{Improvement of the converter}

While the performance of the preliminary and final TRANCCLD systems for half-hourly average $\sum \mathrm{N}_{\mathrm{r}}$ concentration measurements in 2006 and 2007 was equally satisfying (including $\mathrm{NH}_{3}$ ), there is clear indication by the results in Fig. 9 that the preliminary version with an unheated inlet was not able to resolve fast fluctuations of $\mathrm{NH}_{3}$. It may be well assumed that a similar effect occurred for other highly reactive/soluble compounds like $\mathrm{HNO}_{3}$. This problem was solved by complete heating the inlet alloy tube to temperatures $>100^{\circ} \mathrm{C}$ from the very first contact with the sample air. The improved performance of the final TRANC version is also illustrated in Fig. 11 for two cases in 2006 and 2007 with comparable $\mathrm{NH}_{3}$ concentration and emission flux after slurry application. It shows that the emission from the freshly manured field leads to huge short-term fluctuations of the $\mathrm{NH}_{3}$ concentration by more than a factor of three within 2-3 s, which were resolved by the final TRANC version, but obviously not by the preliminary version. The findings emphasize the importance of appropriate inlet characteristics (length, material, temperature, filter use) especially for EC measurements of highly reactive and/or soluble compounds, like $\mathrm{NH}_{3}$. This problem, partly with corresponding solutions, has already been presented for $\mathrm{HNO}_{3}$ by Munger et al. (1996), Horii et al. (2006) and Farmer et al. (2006) and also for $\mathrm{NH}_{3}$ by Brodeur et al. (2008), Whitehead et al. (2008), Ellis et al. (2010) and Sintermann et al. (2011). Beside the use of appropriate inert material, the omission of an inlet filter and (strong) heating of the entire inlet tube were the main recommendations. 
It is, thus, important (although very difficult to achieve) to verify/check the performance of a converter system for EC flux measurements at least for the major included compounds, especially for highly reactive species, under relevant field conditions. Munger et al. (1996), for example, tested and compared the time response characteristics of their $\mathrm{NO}_{\mathrm{y}}$ converter system for $\mathrm{NO}_{2}$ and for $\mathrm{HNO}_{3}$ and found sufficiently fast response with little difference for both compounds, which provided evidence that the converter did not impede transmission of $\mathrm{HNO}_{3}$ fluctuations.

\subsubsection{High-frequency damping and correction}

Despite the fast response characteristic of the TRANC-CLD system with a e-folding response time of $0.3 \mathrm{~s}$ (see Marx et al., 2012), a systematic high-frequency damping loss of of 19-26\% was determined and corrected for in this study. The increase of damping with wind speed (Fig. 7) is expected for damping effects in the sampling tube and analyser, because of the shift of turbulence spectra towards higher frequencies (see e.g., Ammann et al., 2006). However, the relatively weak increase with wind speed indicates also a strong influence of the sensor separation effect, which is not wind speed dependent. The sensor separation distance in the present setup was quite large (about $1 / 4$ of the measurement height) but its effect is supposed to be mitigated by placing the trace gas inlet below the sonic anemometer height (Kristensen et al., 1997).

It is evident that the considerable high-frequency damping loss observed in this study was a consequence of the low measurement height of $1.2 \mathrm{~m}$ (due to the limited field size). For another field application of the TRANC-CLD system (cf. Brümmer et al., 2012) with a measurement height of $4.8 \mathrm{~m}$, the damping was already reduced to about $10 \%$ (Fig. 7). For larger (aerodynamic) measurement heights commonly used above forests, the EC cospectrum will shift to even lower frequencies and, thus, the resulting damping effect may be further reduced. Since in many other cases, similar EC systems are developed and tested initially for application above forests (e.g., Munger et al., 1996; Horii et al., 2006; Farmer et al., 2006), the present study represented an application test under very unfavourable conditions concerning high-frequency damping.

\subsubsection{Inter-comparison with parallel flux measurements}

A full quality assessment or validation of the measured $\sum N_{r}$ fluxes would be even more difficult than for the respective concentrations (Sect. 4.1), because there are few well established flux systems for $\mathrm{N}_{\mathrm{r}}$ compounds available that can serve as a reference. Even for the flux measurement of selected single $\mathrm{N}_{\mathrm{r}}$ compounds (here $\mathrm{NH}_{3}, \mathrm{NO}_{2}$ ), considerable uncertainties have to be expected e.g., due to the general uncertainty of absolute concentration (for $\mathrm{NH}_{3}$ see e.g., von Bobrutzki et al., 2010) or gradient measurements (e.g., Milford et al., 2009), or due to potentially limited spatial representativeness of the chamber measurements. Under these conditions, the qualitative and quantitative agreement of the EC flux measurements for $\sum \mathrm{N}_{\mathrm{r}}$ with the specific $\mathrm{NO}_{\mathrm{X}}$ and $\mathrm{NH}_{3}$ flux measurements yielded satisfying results. Especially for the $\mathrm{NH}_{3}$ emission period after slurry application in 2007 (Fig. 10), the agreement between the $\sum \mathrm{N}_{\mathrm{r}}$ EC flux and the gradient $\mathrm{NH}_{3}$ flux (also taking into account the inferred small $\mathrm{NO}_{2}$ deposition) can be considered as excellent. It is an important indication for the full and fast conversion of the problematic $\mathrm{N}_{\mathrm{r}}$ compound $\mathrm{NH}_{3}$ in the TRANC system. Unfortunately, there is only a very short period available before the slurry application, when the $\sum \mathrm{N}_{\mathrm{r}}$ exchange was not influenced by the slurry application and the fluxes were generally negative with a larger contribution of $\mathrm{NO}_{2}$ deposition. However, the 2006 measurements with the preliminary converter version (virtually excluding the contribution of the $\mathrm{NH}_{3}$ flux) in Figs. 8 and 9 show a good correlation and fair quantitative agreement with the chamber $\mathrm{NO}_{2}$ or total $\mathrm{NO}_{\mathrm{X}}$ fluxes. This indicates an appropriate $\mathrm{NO}_{2}$ flux detection even with the preliminary TRANC version without inlet heating.

In a similar, but longer-term study, Horii et al. (2006) compared EC flux measurements of $\mathrm{NO}_{\mathrm{y}}$ by a gold converter system at the Harvard forest site with single species fluxes of $\mathrm{NO}_{2}$ (parameterised) and $\mathrm{HNO}_{3}$ (inferential method). They found a strongly dominant role of $\mathrm{HNO}_{3}$ deposition over $\mathrm{NO}_{2}$ deposition despite the lower $\mathrm{HNO}_{3}$ ambient concentration due to the much higher (estimated) deposition velocity for $\mathrm{HNO}_{3}$. Such a dominant role of $\mathrm{HNO}_{3}$ deposition was not expected nor observed in the present study, because $\mathrm{NO}_{2}$ and $\mathrm{NH}_{3}$ concentrations were about two orders of magnitude higher than the $\mathrm{HNO}_{3}$ concentrations (see Fig. 2a) due to the closer anthropogenic sources in contrast to the more remote location of the Harvard forest site. This large concentration difference cannot be overcompensated by the different deposition velocity (or surface conductance). It also has to be noted that the deposition velocity over low vegetation like grass is less affected by differences in the surface uptake resistance than for forest.

\subsection{Limitations and potential applications of the $\sum \mathbf{N}_{\mathbf{r}}$ flux system}

\subsubsection{Non-stationarity and implications for EC flux measurements}

The partly large scatter in the $\sum \mathrm{N}_{\mathrm{r}}$ fluxes (as well as in the NOx chamber fluxes) mainly originates from advected variations in the concentration time series of the main $\mathrm{N}_{\mathrm{r}}$ compounds with time scales between about $1 \mathrm{~min}$ and $10 \mathrm{~min}$ ("red noise") at the measurement site (see example in Fig. 3). They cannot be removed by detrending without affecting the flux calculation. The resulting non-stationary conditions can lead to a random noise-like disturbance (error) in the EC flux. It is illustrated in Fig. $4 \mathrm{~d}$ as an additional non-turbulent variation in the covariance function that adds to the pure turbulent 
flux peak signal (e.g., Fig. 4b). Although the applied stationarity test removed the extreme cases, a relatively moderate rejection criteria was used in order to keep a large part of the data. In addition, some apparent outliers may have passed the test accidently.

With the described frequent stationarity problems, it is difficult to determine an instrument related flux detection limit at the study site. It has to be assumed that the observed variability for low fluxes around zero was mainly caused by non-stationarity rather than by instrument related noise. In order to estimate an upper limit for the flux detection limit, we chose the two nights between 22 and 24 October 2007 (see Fig. 10). Because of persistently high wind speed (3-5 $\mathrm{m} \mathrm{s}^{-1}$ ) and almost constant wind direction from northnortheast (without major anthropogenic sources), the $\mathrm{N}_{\mathrm{r}}$ concentrations remained relatively low and stable and the fluxes were generally small (slightly negative). For these favourable stationary conditions the standard deviation of the individual half-hourly fluxes was 2.1 and $2.6 \mathrm{ng}-\mathrm{N} \mathrm{m}^{-2} \mathrm{~s}^{-1}$ for the two nights, respectively. The resulting $2 \sigma$ uncertainty of about $5 \mathrm{ng}-\mathrm{N} \mathrm{m}^{-2} \mathrm{~s}^{-1}$ may be regarded as an upper limit estimate for the instrument/method related half-hourly flux detection limit of the $\sum \mathrm{N}_{\mathrm{r}}$ eddy covariance system. While it can be expected that the real detection limit (valid e.g., for remote sites with homogenous surroundings and generally low $\mathrm{N}_{\mathrm{r}}$ concentrations and fluxes) is significantly lower, this needs to be checked in corresponding field applications. For the EC measurement of NO fluxes with the same CLD analyser, Rummel et al. (2002) estimated a flux detection limit due to instrumental noise of only $0.07 \mathrm{ng}-\mathrm{N} \mathrm{m}^{-2} \mathrm{~s}^{-1}$.

\subsubsection{Potential applications of the integral $\sum N_{r}$ flux system (outlook)}

Although within the present study the TRANC-CLD system was operated in the field only for selected campaigns (few weeks to months), it has a good potential for continuous $\sum \mathrm{N}_{\mathrm{r}}$ flux monitoring over long periods. In a companion paper, Brümmer et al. (2012) report on a multi-month field application of the same system at an agricultural site in Gebesee, Germany, that allowed the quantification of the annual $\mathrm{N}_{\mathrm{r}}$ exchange budget. Since the maintenance requirements are relatively moderate and mainly concern the supply of operation and calibration gases and occasional cleaning of the converter inner surfaces and filter (depending on the air pollution level at the site), the TRANC-CLD system seems well suited for long-term and integral monitoring the biosphereatmosphere exchange of $\sum \mathrm{N}_{\mathrm{r}}$ of agricultural ecosystems as well as of (semi-) natural ecosystems like forests. The system would be an "ideal" complement for GHG monitoring stations also based on EC measurements (e.g., FLUXNET, ICOS). Especially for nitrogen limited systems, the annual $\sum \mathrm{N}_{\mathrm{r}}$ input is important for interpreting observed carbon sequestration or loss (e.g., Sutton et al., 2008). The coherent exchange measurements of GHGs and $\sum \mathrm{N}_{\mathrm{r}}$ with the same method and coherent flux footprint/source area would facilitate the interpretation and modelling of the measurements. In the present configuration the TRANC-CLD system with the necessary vacuum pump needs mains power or a robust and stable generator (total ca. $700 \mathrm{~W}$ ). These power requirements are similar as for fast response closed-path $\mathrm{CH}_{4}$ and $\mathrm{N}_{2} \mathrm{O}$ analysers currently used for eddy covariance GHG flux monitoring.

In specific cases with a strong dominance of a single (emitted) $\mathrm{N}_{\mathrm{r}}$ compound, as met in this study for $\mathrm{NH}_{3}$ after slurry application, the TRANC-CLD derived fluxes can also yield important information on the flux magnitude and dynamics of the respective compound. As illustrated in Fig. 11, the final TRANC-CLD system is able to measure fast fluctuations of the problematic compound $\mathrm{NH}_{3}$ over large concentration ranges. For fast detection of $\mathrm{NH}_{3}$ with a specific massspectrometric method, Sintermann et al. (2011) had to use strong heating of all wetted parts: from the sampling inlet and the high-flow sampling tube till the detection cell (ion drift tube) within the instrument.

It is clear that an extension of the TRANC-CLD flux system with additional more compound specific information would be desirable. If more than one CLD analyser (or an instrument with more than one detection channel) are available, the $\sum \mathrm{N}_{\mathrm{r}}$ flux measurements by the TRANC could be complemented by $\mathrm{NO}$ (no converter), $\mathrm{NO}_{2}$ (photolytic converter), or $\mathrm{NO}_{\mathrm{y}}$ (gold converter) flux measurements. Priority would have the separation of potentially relevant emission fluxes (of $\mathrm{NO}$ or eventually $\mathrm{NH}_{3}$ ) from deposition fluxes (all other $\mathrm{N}_{\mathrm{r}}$ compounds).

\section{Conclusions}

The TRANC-CLD system has been tested and applied for EC flux measurements of the $\sum \mathrm{N}_{\mathrm{r}}$ exchange at an agricultural site in Switzerland. As already shown by Marx et al. (2012), the presented concentration measurements demonstrate that the system reliably detects the sum of the individually measured oxidized and reduced $\mathrm{N}_{\mathrm{r}}$ compounds. Due to its fast response characteristics it is able to measure EC fluxes of $\sum \mathrm{N}_{\mathrm{r}}$. The position of the converter at the sample inlet ensures a minimum interaction between the reactive $\mathrm{N}_{\mathrm{r}}$ compounds and the measurement system leading to a moderate high-frequency damping loss and correction of $19-26 \%$ for the low measurement height of $1.2 \mathrm{~m}$.

Despite the non-ideal conditions (nearby sources, nonstationarity) at the field site, the present measurements allowed to validate the capability of the $\sum \mathrm{N}_{\mathrm{r}}$ flux system against parallel measurements of $\mathrm{NO}_{\mathrm{X}}$ fluxes by dynamic chambers and of $\mathrm{NH}_{3}$ measurements by the aerodynamic gradient technique. While $\mathrm{NO}_{2}$ deposition fluxes were generally recovered, the final converter version with improved inlet heating was also able to well recover ammonia emission fluxes. 
Although a mechanistic interpretation of species specific exchange processes is hardly possible with the $\sum \mathrm{N}_{\mathrm{r}}$ flux alone, it provides valuable information about the longer-term cumulative $\mathrm{N}_{\mathrm{r}}$ exchange important for the interpretation and modelling of the ecosystem pollution load and nutrient status. Under special conditions or in combination with additional specific measurements, it can also represent an useful constraint for exchange processes in the short term.

Acknowledgements. This work was supported by the Swiss State Secretariat for Education and Research (Project No. C09.0028) under the framework of the COST action ABBA (ES0804), and by the EU project NitroEurope-IP (Contract 017841) under the EC 6th Framework Programme for Research and Technological Development. We would like to thank the Max Planck Institute (MPI) for Biogeochemistry in Jena, Germany, for supporting the development of the TRANC system. We are also grateful to Chris Flechard, Christoph Spirig, Markus Jocher who performed the individual $\mathrm{N}_{\mathrm{r}}$ compound measurements and helped with the field work.

Edited by: E. Nemitz

\section{References}

Ammann, C., Brunner, A., Spirig, C., and Neftel, A.: Technical note: Water vapour concentration and flux measurements with PTR-MS, Atmos. Chem. Phys., 6, 4643-4651, doi:10.5194/acp6-4643-2006, 2006.

Ammann, C., Flechard, C., Leifeld, J., Neftel, A., and Fuhrer, J.: The carbon budget of newly established temperate grassland depends on management intensity, Agr. Ecosyst. Environ., 121, 520, 2007.

Ammann, C., Spirig, C., Leifeld, J., and Neftel, A.: Assessment of the Nitrogen and Carbon Budget of Two Managed Grassland Fields, Agr. Ecosyst. Environ., 133, 150-162, 2009.

Aubinet, M., Grelle, A., Ibrom, A., Rannik, Ü., Moncrieff, J., Foken, T., Kowalski, A. S., Martin, P. H., Berbigier, P., Bernhofer, C., Clement, R., Elbers, J., Granier, A., Grünwald, T., Morgenstern, K., Pilegaard, K., Rebmann, C., Snijders, W., Valentini, R., and Vesala, T.: Estimates of the annual net carbon and water exchange of forests: the EUROFLUX methodology, Adv. Ecol. Res. 30, 113-171, 2000.

BAFU: NABEL Luftbelastung 2007, Messresultate des Nationalen Beobachtungsnetzes für Luftfremdstoffe, Bundesamt für Umwelt, Bern, 139 pp., available at: www.umwelt-schweiz. ch/uz-0823-d, 2008.

Baldocchi, D. D.: Assessing the eddy covariance technique for evaluating carbon dioxide exchange rates of ecosystems: past, present and future, Glob. Change Biol., 9, 479-492, 2003.

Baldocchi, D. D., Falge, E., Gu, L. H., Olson, R., Hollinger, D., Running, S., Anthoni, P., Bernhofer, C., Davis, K., Evans, R., Fuentes, J., Goldstein, A., Katul, G., Law, B., Lee, X. H., Malhi, Y., Meyers, T., Munger, W., Oechel, W., U, K. T. P., Pilegaard, K., Schmid, H. P., Valentini, R., Verma, S., Vesala, T., Wilson, K., and Wofsy, S.: FLUXNET: a new tool to study the temporal and spatial variability of ecosystem scale carbon dioxide, wa- ter vapor, and energy flux densities, B. Am. Meteorol. Soc., 82, 2415-2434, 2001.

Brodeur, J. J., Warland, J. S., Staebler, R. M., and Wagner-Riddle, C.: Technical note: Laboratory evaluation of a tunable diode laser system for eddy covariance measurements of ammonia flux, Agr. Forest Meteorol., 149, 385-391, 2008.

Brümmer, C., Marx, O., Kutsch, W. L., Ammann, C., Wolff, V., Fléchard, C. R., and Freibauer, A.: Fluxes of total reactive atmospheric nitrogen using eddy covariance above arable land, submitted to Tellus B, 2012.

Civerolo, K. L. and Dickerson, R. R.: Nitric oxide soil emissions from tilled and untilled cornfields, Agr. Forest Meteorol., 90, 307-311, 1998.

Clemitshaw, K.: A Review of Instrumentation and Measurement Techniques for Ground-Based and Airborne Field Studies of Gas-Phase Tropospheric Chemistry, Crit. Rev. Env. Sci. Tec., 34, 1-108, 2004.

Dabberdt, W. F., Lenschow, D. H., Horst, T. W., Zimmerman, P. R., Oncley, S. P., and Delany, A. C.: Atmosphere-surface exchange measurements, Science, 260, 1472-1481, 1993.

Delany, A. C., Fitzjarrald, D. R., Lenschow, D. H., Pearson, R., Wendel, G. J., and Woodruff, B.: Direct measurements of nitrogen oxides and ozone over grassland, J. Atmos. Chem., 4, 429444, 1986.

Ellis, R. A., Murphy, J. G., Pattey, E., van Haarlem, R., O'Brien, J. M., and Herndon, S. C.: Characterizing a Quantum Cascade Tunable Infrared Laser Differential Absorption Spectrometer (QCTILDAS) for measurements of atmospheric ammonia, Atmos. Meas. Tech., 3, 397-406, doi:10.5194/amt-3-397-2010, 2010.

Erisman J. W., Bleeker A., Galloway J., and Sutton M. S.: Reduced nitrogen in ecology and the environment, Environ. Pollut., 150, 140-149, 2007.

Eugster, W. and Hesterberg, R.: Transfer resistances of $\mathrm{NO}_{2}$ determined from eddy correlation flux measurements over a litter meadow at a rural site on the Swiss Plateau, Atmos. Environ., 30, 1247-1254, 1996.

Fahey, D. W., Eubank, C. S., Hubler, G., and Fehsenfeld, F. C.: Evaluation of a catalytic reduction technique for the measurement of total reactive odd-nitrogen $\mathrm{NO}_{\mathrm{y}}$ in the atmosphere, J. Atmos. Chem., 3, 435-468, 1985.

Famulari, D., Fowler, D., Nemitz, E., Hargreaves, K. J., StoretonWest, R. L., Rutherford, G., Tang, Y. S., Sutton, M. A., and Weston, K. J.: Development of a low-cost system for measuring conditional time-averaged gradients of $\mathrm{SO}_{2}$ and $\mathrm{NH}_{3}$, Environ. Monit. Assess., 161, 11-27, doi:10.1007/s10661-008-07236, 2009.

Farmer, D. K., Wooldridge, P. J., and Cohen, R. C.: Application of thermal-dissociation laser induced fluorescence (TD-LIF) to measurement of $\mathrm{HNO}_{3}$, $\sum$ alkyl nitrates, $\sum$ peroxy nitrates, and $\mathrm{NO}_{2}$ fluxes using eddy covariance, Atmos. Chem. Phys., 6, 3471-3486, doi:10.5194/acp-6-3471-2006, 2006.

Farmer, D. K., Kimmel, J. R., Phillips, G., Docherty, K. S., Worsnop, D. R., Sueper, D., Nemitz, E., and Jimenez, J. L.: Eddy covariance measurements with high-resolution time-offlight aerosol mass spectrometry: a new approach to chemically resolved aerosol fluxes, Atmos. Meas. Tech., 4, 1275-1289, doi:10.5194/amt-4-1275-2011, 2011.

Flechard, C. R., Spirig, C., Neftel, A., and Ammann, C.: The annual ammonia budget of fertilised cut grassland - Part 2: Seasonal 
variations and compensation point modeling, Biogeosciences, 7 , 537-556, doi:10.5194/bg-7-537-2010, 2010.

Flechard, C. R., Nemitz, E., Smith, R. I., Fowler, D., Vermeulen, A. T., Bleeker, A., Erisman, J. W., Simpson, D., Zhang, L., Tang, Y. S., and Sutton, M. A.: Dry deposition of reactive nitrogen to European ecosystems: a comparison of inferential models across the NitroEurope network, Atmos. Chem. Phys., 11, 2703-2728, doi:10.5194/acp-11-2703-2011, 2011.

Foken, T. and Wichura, B.: Tools for quality assessment of surfacebased flux measurements, Agr. Forest Meteorol., 78, 83-105, 1996.

Hicks, B. B., Baldocchi, D. D., Meyers, T. P., Hosker Jr., R. P., and Matt, D. R.: A preliminary multiple resistance routine for deriving dry deposition velocities from measured quantities, Water Air Soil Pollut., 36, 311-330, 1987.

Hogberg, P.: Nitrogen impact on forest carbon, Nature, 447, 781782, 2007

Horii, C. V., Munger, J. W., Wofsy, S. C., Zahniser, M., Nelson, D., and McManus, J. B.: Fluxes of nitrogen oxides over a temperate deciduous forest, J. Geophys. Res. 109, D08305, doi:10.1029/2003JD004326, 2004.

Horii, C. V., Munger, J. W., Wofsy, S. C., Zahniser, M., Nelson, D., and McManus, J. B.: Atmospheric reactive nitrogen concentration and flux budgets at a Northeastern U.S. forest site, Agr. Forest Meteorol., 136, 159-174, 2006.

Kristensen, L., Mann, J., Oncley, S. P., and Wyngaard, J. C.: How close is close enough when measuring scalar fluxes with displaced sensors?, J. Atmos. Ocean. Technol., 14, 814-821, 1997.

Lamarque, J. F., Kiehl, J. T., Brasseur, G. P., Butler, T., CameronSmith, P., Collins, W. D., Collins, W. J., Granier, C., Hauglustaine, D., Hess, P. G., Holland, E. A., Horowitz, L., Lawrence, M. G., McKenna, D., Merilees, P., Prather, M. J., Rasch, P. J., Rotman, D., Shindell, D., and Thornton, P.: Assessing future nitrogen deposition and carbon cycle feedback using a multimodel approach: Analysis of nitrogen deposition, J. Geophys. Res., 110, D19303, doi:10.1029/2005JD005825, 2005.

Li, Y., Aneja, V. P., Arya, S. P., Rickman, J., Brittig, J., Roelle, P., and Kim, D. S.: Nitric oxide emission from intensively managed agricultural soil in North Carolina, J. Geophys. Res., 104, 2611526123, 1999.

Magnani, F., Mencuccini, M., Borghetti, M., Berbigier, P., Berninger, F., Delzon, S., Grelle, A., Hari, P., Jarvis, P. G., Kolari, P., Kowalski, A. S., Lankreijer, H., Law, B. E., Lindroth, A., Loustau, D., Manca, G., Moncrieff, J. B., Rayment, M., Tedeschi, V., Valentini, R., and Grace, J.: The human footprint in the carbon cycle of temperate and boreal forests, Nature, 447, 848-851, 2007.

Marx, O.: Validierung eines $\mathrm{NO}_{\mathrm{y}}$-Messverfahrens in EddyKovarianz-Technik, Diploma thesis, Faculty of Chemical and Earth Sciences, Friedrich-Schiller University, Jena, 70 pp., 2004.

Marx, O., Freibauer, A., Einax, J. W., and Schulze E.-D.: Development and Validation of Instrumentation to determine the atmosphere-biosphere Exchange of reactive Nitrogen by Eddycovariance Flux Measurements, Geophys. Res. Abstr., 8, 02881, SRef-ID: 1607-7962/gra/EGU06-A-02881, 2006.

Marx, O., Brümmer, C., Ammann, C., Wolff, V., and Freibauer, A.: TRANC - a novel fast-response converter to measure total reactive atmospheric nitrogen, Atmos. Meas. Tech., 5, 1045-1057, doi:10.5194/amt-5-1045-2012, 2012.
McCalley, C. K. and Sparks, J. P.: Controls over nitric oxide and ammonia emissions from Mojave Desert soils, Oecologia, 156, 871-881, 2008.

Meixner, F. X.: Surface exchange of odd nitrogen oxides, Nova Ac. LC., 70, 299-348, 1994.

Milford, C., Theobald, M. R., Nemitz, E., Hargreaves, K. J., Horvath, L., Raso, J., Dämmgen, U., Neftel, A., Jones, S. K., Hensen, A., Loubet, B., Cellier, P., and Sutton, M. A.: Ammonia fluxes in relation to cutting and fertilization of an intensively managed grassland derived from an inter-comparison of gradient measurements, Biogeosciences, 6, 819-834, doi:10.5194/bg-6-819-2009, 2009.

Munger, J. W., Wofsy, S. C., Bakwin, P. S., Fan, S.-M., Goulden, M. L., Daube, B. C., and Goldstein, A. H.: Atmospheric deposition of reactive nitrogen oxides and ozone in a temperate deciduous forest and a subarctic woodland: 1. Measurements and mechanisms, J. Geophys. Res. 101, 12639-12657, 1996.

Nemitz, E., Sutton, M. A., Wyers, G. P., and Jongejan, P. A. C.: Gas-particle interactions above a Dutch heathland: I. Surface exchange fluxes of $\mathrm{NH}_{3}, \mathrm{SO}_{2}, \mathrm{HNO}_{3}$ and $\mathrm{HCl}$, Atmos. Chem. Phys., 4, 989-1005, doi:10.5194/acp-4-989-2004, 2004.

Nemitz, E., Jimenez, J. L., Huffman, J. A., Ulbrich, I. M., Canagaratna, M. R., Worsnop, D. R., and Guenther, A. B.: An eddycovariance system for the measurement of surface/atmosphere exchange fluxes of submicron aerosol chemical species - First application above an urban area, Aerosol Sci. Tech., 42, 636657, 2008.

Pape, L., Ammann, C., Nyfeler-Brunner, A., Spirig, C., Hens, K., and Meixner, F. X.: An automated dynamic chamber system for surface exchange measurement of non-reactive and reactive trace gases of grassland ecosystems, Biogeosciences, 6, 405429, doi:10.5194/bg-6-405-2009, 2009.

Pollack, I. B., Lerner, B. M., and Ryerson, T. B.: Evaluation of ultraviolet light-emitting diodes for detection of atmospheric $\mathrm{NO}_{2}$ by photolysis - chemiluminescence, J. Atmos. Chem., 65, 111-125, 2010 .

Rummel, U., Ammann, C., Gut, A., Meixner, F. X., and Andreae, M. O.: Eddy covariance measurements of nitric oxide flux within an Amazonian rain forest, J. Geophys. Res., 107, 8050, doi:10.1029/2001JD000520, 2002.

Schulze, E. D., Ciais, P., Luyssaert, S., Schrumpf, M., Janssens, I. A., Thiruchittampalam, B., Theloke, J., Saurat, M., Bringezu, S., Lelieveld, J., Lohila, A., Rebmann, C., Jung, M., Bastviken, D., Abril, G., Grassi, G., Leip, A., Freibauer, A., Kutsch, W., Don, A., Nieschulze, J., Borner, A., Gash, J. H., and Dolman, A. J.: The European carbon balance, Part 4: integration of carbon and other trace-gas fluxes, Glob. Change Biol., 16, 1451-1469, 2010.

Sintermann, J., Spirig, C., Jordan, A., Kuhn, U., Ammann, C., and Neftel, A.: Eddy covariance flux measurements of ammonia by high temperature chemical ionisation mass spectrometry, Atmos. Meas. Tech., 4, 599-616, doi:10.5194/amt-4-599-2011, 2011.

Skiba, U., Drewer, J., Tang, Y. S., van Dijk, N., Helfter, C., Nemitz, E., Famulari, D., Cape, J. N., Jones, S. K., Twigg, M., Pihlatie, M., Vesala, T., Larsen, K. S., Carter, M. S., Ambus, P., Ibrom, A., Beier, C., Hensen, A., Frumau, A., Erisman, J. W., Bruggemann, N., Gasche, R., Butterbach-Bahl, K., Neftel, A., Spirig, C., Horvath, L., Freibauer, A., Cellier, P., Laville, P., Loubet, B., Magliulo, E., Bertolini, T., Seufert, G., Andersson, M., Manca, G., Laurila, T., Aurela, M., Lohila, A., Zechmeister-Boltenstern, 
S., Kitzler, B., Schaufler, G., Siemens, J., Kindler, R., Flechard, C., and Sutton, M. A.: Biosphere-atmosphere exchange of reactive nitrogen and greenhouse gases at the NitroEurope core flux measurement sites: Measurement strategy and first data sets, Agr. Ecosyst. Environ., 133, 139-149, 2009.

Soussana, J. F., Allard, V., Pilegaard, K., Ambus, P., Ammann, C., Campbell, C., Ceschia, E., Clifton-Brown, J., Czobel, S., Domingues, R., Flechard, C., Fuhrer, J., Hensen, A., Horvath, L., Jones, M., Kasper, G., Martin, C., Nagy, Z., Neftel, A., Raschi, A., Baronti, S., Rees, R. M., Skiba, U., Stefani, P., Manca, G., Sutton, M., Tuba, Z., and Valentini, R.: Full accounting of the greenhouse gas $\left(\mathrm{CO}_{2}, \mathrm{~N}_{2} \mathrm{O}, \mathrm{CH}_{4}\right)$ budget of nine European grassland sites, Agr. Ecosyst. Environ., 121, 121-134, 2007.

Spirig, C., Flechard, C. R., Ammann, C., and Neftel, A.: The annual ammonia budget of fertilised cut grassland - Part 1: Micrometeorological flux measurements and emissions after slurry application, Biogeosciences, 7, 521-536, doi:10.5194/bg-7-5212010, 2010.

Steinbacher, M., Zellweger, C., Schwarzenbach, B., Bugmann, S., Buchmann, B., Ordonez, C., Prevot, A. S. H., and Hueglin, C.: Nitrogen oxide measurements at rural sites in Switzerland: Bias of conventional measurement techniques, J. Geophys. Res., 112, D11307, doi:10.1029/2006JD007971, 2007.

Sutton, M. A., Nemitz, E., Milford, C., Fowler, D., Moreno, J., San José, R., Wyers, G. P., Otjes, R. P., Harrison, R., Husted, S., and Schjorring, J. K.: Micrometeorological measurements of net ammonia fluxes over oilseed rape during two vegetation periods, Agr. Forest Meteorol., 105, 351-369, 2000.

Sutton, M. A., Simpson, D. D., Levy, P. E., Smith, R. I., Reis, S., van Oijen, M., and de Vries, W.: Uncertainties in the relationship between atmospheric nitrogen deposition and forest carbon sequestration, Glob. Change Biol., 14, 2057-2063, 2008.
Thomas, R. M., Trebs, I., Otjes, R., Jongejan, P. A. C., ten Brink, H., Philips G., Kortner, M., Meixner, F. X., and Nemitz, E.: An automated analyser to measure surface-atmosphere exchange fluxes of water soluble inorganic aerosol compounds and reactive gases, Environ. Sci. Technol., 43, 1412-1418, 2009.

UNECE: Protocol to the 1979 Convention on long-range transboundary air pollution to abate acidification, eutrophication and ground-level ozone. United Nations Economic Commission for Europe, Geneva, 69 pp., available at: www.unece.org/fileadmin/ DAM/env/lrtap/fulltext/1999Multi.E.Amended.2005.pdf, 1999.

von Bobrutzki, K., Braban, C. F., Famulari, D., Jones, S. K., Blackall, T., Smith, T. E. L., Blom, M., Coe, H., Gallagher, M., Ghalaieny, M., McGillen, M. R., Percival, C. J., Whitehead, J. D., Ellis, R., Murphy, J., Mohacsi, A., Pogany, A., Junninen, H., Rantanen, S., Sutton, M. A., and Nemitz, E.: Field inter-comparison of eleven atmospheric ammonia measurement techniques, Atmos. Meas. Tech., 3, 91-112, doi:10.5194/amt-3-91-2010, 2010.

Webb, E. K., Pearman, G. I., and Leuning, R.: Correction of flux measurements for density effects due to heat and water vapour transfer, Quart. J. Roy. Meteorol. Soc., 106, 85-100, 1980.

Whitehead, J. D., Twigg, M., Famulari, D., Nemitz, E., Sutton, M., Gallagher, M. W., and Fowler, D.: Evaluation of Laser Absorption Spectroscopic Techniques for Eddy Covariance Flux Measurements of Ammonia, Environ. Sci. Technol., 42, 2041-2046, 2008.

Wolff, V., Trebs, I., Ammann, C., and Meixner, F. X.: Aerodynamic gradient measurements of the $\mathrm{NH}_{3}-\mathrm{HNO}_{3}-\mathrm{NH}_{4} \mathrm{NO}_{3}$ triad using a wet chemical instrument: an analysis of precision requirements and flux errors, Atmos. Meas. Tech., 3, 187-208, doi:10.5194/amt-3-187-2010, 2010. 